Frederik Kortlandt, Leiden University, www.kortlandt.nl

\title{
More on the chronology of Celtic sound changes
}

Graham Isaac's recent monograph (2007) deals with the chronology of Celtic sound changes. Remarkably, the author completely disregards the relative chronology which I published 28 years earlier (1979). In the following I shall discuss the main issues on which our views differ.

1. Following Thurneysen (1946: 435), Isaac derives Old Irish -ír 'granted' from ${ }^{*}$ peper- or ${ }^{*}$ pepor- (p. 15). I have argued that ${ }^{*} p$ developed into a bilabial fricative $[\varphi]$ which was preserved into the separate languages (1982: 74-76 $=2007: 53-55)$. It merged with ${ }^{\star} W$ after ${ }^{{ }} s$ in Irish and coalesced with a preceding ${ }^{{ }^{*}} s$ into ${ }^{\star} f$ in British, e.g. OIr. seir 'heel', dual di pherid, Welsh ffer 'ankle'. The loss of the labial articulation was obviously posterior to the lenition, as it was in OIr. secht 'seven', necht 'niece', lassar 'flame', Welsh saith, nith, llachar. The voiceless bilabial fricative $[\varphi]$ merged with its voiced counterpart [ $\beta$ ] in OIr. -ebra 'he will bestow' $<{ }^{*}$ piprā- and -ebla 'he will drive' $<{ }^{*}$ piplā- (cf. Thurneysen 1946: 403). Before ${ }^{\star} n$, the reflex of ${ }^{*} p$ merged with ${ }^{*} u$ after ${ }^{\star} O$ and ${ }^{\star}$ a but was lost after ${ }^{\star} e$, e.g. súan 'sleep' < ${ }^{\star}$ sopno-, cúan 'harbour' < ${ }^{\star} k a p n o-$, tene 'fire' $<{ }^{\star}$ tepnet-. These developments were more recent than the merger of ${ }^{\star} e u$ with ${ }^{\star}$ au and ${ }^{\star}$ ou into ${ }^{\star}$ ou, which was more recent than the loss of intervocalic ${ }^{\star} s$ (cf. Greene 1976: 27) but earlier than the monophthongization of the latter into ${ }^{\star} \bar{o}_{2}$, so that the merger of ${ }^{*} p$ with ${ }^{*} u$ before ${ }^{\star} n$ can be dated between stages 2 and 3 of my chronology (1979: 39). Intervocalic ${ }^{\star} p$ was lost, e.g. saer 'artificer' < ${ }^{\star}$ sapero-, té 'hot' < ${ }^{*}$ tepent-, ni(a)e 'nephew' < ${ }^{*}$ nepot-, íar 'after' < ${ }^{\star}$ epi-. Since ${ }^{*}$ epi- shared the monophthongization of ${ }^{*} e i$ to ${ }^{\star} \bar{e}_{2}$, the loss of intervocalic ${ }^{*} p$ can be dated before stage 3 of my chronology (1979: 40). In other positions, the reflexes $[\mathrm{h}]<{ }^{*} s$ and $[\varphi]<{ }^{*} p$ were preserved up to a later stage, e.g. in lenited $p h-<{ }^{*} s p-$. As I pointed out earlier (1982: 75), OIr. timme 'heat' represents ${ }^{\star}$ tepsmiā, not ${ }^{\star}$ tepesmiā. The sequence ${ }^{\star}$ epe merged with ${ }^{\star}$ ese, yielding ${ }^{\star} \bar{e}_{3}$ (cf. Kortlandt 1979: 41), not ${ }^{*}$.

I have dated the hiatal raising of ${ }^{*} e$ to ${ }^{*} i$ before back vowels, e.g. in ni(a)e 'nephew', gen.sg. niath, niad $<{ }^{\star}$ nepotos, siur 'sister', acc.sg. sieir $<{ }^{\star}$ swesoram, dual sieir $<{ }^{*}$ swesore, between stages 3 and 6 of my chronology (2007: 140), after the lenition (1) but before the (first) palatalization (7), the raising of ${ }^{\star} e$ and ${ }^{\star} o$ before a high vowel in the following syllable (8), and the lowering of ${ }^{{ }^{*}} i$ and ${ }^{*} u$ before a nonhigh vowel in the following syllable (11). Isaac mistakenly posits a raising of unstressed ${ }^{*} e$ before ${ }^{\star} s$ anterior to the lenition in 2 nd sg. biri 'carry' $<{ }^{\star}$ berisi $<{ }^{\star}$ beresi (p. 16), ignoring the original endings of the Indo-European thematic inflection (cf. Kortlandt $1979,1984,1997 \mathrm{a}$ and 2007 passim). He mistakenly limits the raising of ${ }^{*} e$ to ${ }^{*} i$ to the stressed syllable (cf. Schrijver 1995: 387 and Kortlandt 2007: 140). Following McCone, he mistakenly dates the shortening of long vowels in medial syllables (my stage 10) before the raising (my stage 8) in his discussion of niad $<{ }^{*}$ nepotos and cucann 'kitchen', Welsh cegin < Latin coquina (p. 19, cf. Kortlandt 1997b = 2007: 117-120).

2. While Isaac dates the loss of ${ }^{*} p$ and the raising of ${ }^{*} \bar{e}_{1}$ to ${ }^{{ }_{i}}$ to Proto-Celtic (p. 21), I have dated these developments to early stages of Proto-Irish postdating the lenition (1979: 40). In another study (1981: 1-16 = 2007: 25-44) I discussed the ItaloCeltic shortening of pretonic long vowels discovered by Dybo (1961) and its 
interpretation by Illič-Svityč (1962). I have claimed that the Italo-Celtic shortening affected pretonic ${ }^{\star} \bar{e},{ }^{\star} \bar{a},{ }^{*} \bar{o}$ but not sequences of resonant plus laryngeal, where the long vowel had not yet originated (1981: 13f. $=2007$ : 4of.), and that the long vowel never originated in pretonic sequences of laryngeal plus resonant such as ${ }^{*} g^{w} \mathrm{Hi}$ - 'live' and ${ }^{\star} b^{h} \mathrm{Hu}$ - 'be' (1981: 15f. = 2007: 43f.). The discussion was continued by Schrijver (1991: 334-357, 512-536 and 1995: 168-191). Isaac rejects the derivation of OIr. sith'long', Welsh hyd 'length' $<{ }^{*}{ }_{s} H_{1}$ i- beside OIr. sír, Welsh hir $<{ }^{*} s_{s} H_{1^{-}}$(p. 24) in spite of such obvious parallels as PIE ${ }^{\star} d^{h} e H_{1}(i)$ - 'to suck', ${ }^{\star} l e H_{1}(i)$ - 'to pour', ${ }^{*} p e H_{3}(i)$ - 'to drink'. He subscribes to the criticism of pretonic shortening by Irslinger and Rasmussen (p. 25). In fact, Irslinger misrepresents the issue by substituting ${ }^{\star} R H$ for ${ }^{\star} \mathrm{HR}$ and by rejecting a metathesis ${ }^{\star} \mathrm{CeHU}>{ }^{*} \mathrm{CeUH}$ which nobody ever proposed (2002: 28). Rasmussen's complaint that my view "is at variance with everything we know about IE syllabification" (1999: 170') should be remedied by a conscientious study of Werner Winter's pertinent article (1965) and by abandonment of his preconceived ideas about Indo-European, followed by a discussion of my arguments. Isaac's dismissal of my reconstruction ${ }^{\star} H R$ in cases of shortening as circular is mistaken because this reconstruction is supported by full grade forms with ${ }^{\star} V H R$. His peculiar comparison of Latvian dzîvs, Lith. gývas 'living' with Latvian plâns, Lith. plónas 'thin' obscures the issue because the latter word has a full grade vowel ${ }^{\star} V H$. Eventually he devises a highly unnatural, complex and unconvincing phonetic rule on the basis of a host of additional assumptions in order to explain the data without recourse to analogy. It is a typical example of paper phonetics. Isaac's proposal to derive the short vowel of Latin vir 'man' from nom.sg. ${ }^{*}$ Vĭr $z<{ }^{*}$ Vïrz $<{ }^{*}$ Vïros (p. 57f.) does not explain the short vowel of the Old Irish cognate fer.

3. Isaac presents a relative chronology of 25 sound changes from Proto-IndoEuropean to Celtic (pp. 62-64). He mistakenly thinks that the circumflex of Lith. taũras 'aurochs' is compatible with a reconstruction ${ }^{\star *}$ taHuros (p. 65), cf. acc.sg. díeveri 'brother-in-law' $<{ }^{\star}$ daHiuerm, píemeni 'shepherd' $<{ }^{*}$ poHimenm. The word is an early European borrowing from Semitic. I cannot accept all stages of Isaac's relative chronology (pp. 69-74). I have dated the split of ${ }^{{ }^{*}} \bar{o}_{1}$ into ${ }^{*} \bar{a}$ and ${ }^{*} \bar{u}$ (Isaac 22) before the rise of ${ }^{\star} \bar{e}_{3}$ (Isaac 21) and the raising of ${ }^{{ }^{*}} \bar{e}_{1}$ to ${ }^{{ }^{*}} \bar{i}$ (Isaac 17) between these two developments (1979: 39-41 = 2007: 6-9). I think that the loss of the laryngeals (Isaac 7 and 18$)$ can largely be dated to the Italo-Celtic period. Isaac's anaptyctic shwa (5, 13a, $20)$ is a heterogeneous phenomenon which can partly be dated to the Italo-Celtic period (cf. Kortlandt 2007: 88). There was no phonetic reduction of ${ }^{*} y e$ to ${ }^{*} i$ between consonants (Isaac 19, cf. Kortlandt 2007: 137). The development of ${ }^{*} p$ (Isaac 12a, 14, 15, 16) was discussed above. Isaac's earlier rules are Proto-Celtic $(6,10,11)$, Italo-Celtic (5, $7,8,9)$, dialectal Indo-European (3), or speculative $(2,4)$. I am sorry that Isaac has found it unnecessary to discuss the arguments for the chronology which I put forward earlier.

4. Isaac reconstructs ${ }^{*} \hat{g}^{h}$ dies $>{ }^{*} \hat{g}^{h} d^{h} y e s>{ }^{*} g^{h} d^{h} e s>$ Greek $\chi \theta \dot{\varepsilon} \varsigma$ 'yesterday', with loss of the dental stop in Sanskrit hyáh, Latin herīand German gestern but loss of the palatal stop in Welsh doe and Albanian dje (p. 75). He assumes metathesis in Greek ${ }^{*} d^{h} g^{h}$ omios $>{ }^{*} g^{h} d^{h}$ onyos $>\chi \theta$ óvioৎ 'of the earth' and its cognate OIr. duine, Welsh dyn 'man' (p. 78) but not in Sanskrit kșám- 'earth', Gothic guma 'man', Latin humus, homo, Albanian dhe (p. 81), to which Lith. žẽmé, Slavic zemlja, Thracian $\Sigma \varepsilon \mu \varepsilon \dot{\lambda} \eta$ and 
Phrygian $\zeta \varepsilon ́ \mu \varepsilon \lambda \varepsilon v$ can be added. It seems to me that none of these examples supports the hypothesis of an early dialectal Indo-European development or later language contact. All forms can be derived from ${ }^{\star} t k^{k}$, ${ }^{*} d^{h} \hat{g}^{h}$-, with loss of the second component in Proto-Celtic times. I also reject the derivation of Latin sitis 'thirst', situs 'mould' < ${ }^{\star} d^{h} g^{w h} i t i / u$ - and situs 'located, site' < ${ }^{\star} t k i t o / u$ - (p. 79). The former words may be related to Sanskrit jásate 'be exhausted', Greek $\sigma \beta \varepsilon$ ćvvī $\mu$ ' extinguish' and the latter to Latin sileō 'be silent' (cf. de Vaan 2008: 563f.). No conclusions can be based on the word ursus 'bear'.

Following Melchert (1994: 251f.), Isaac assumes three series of velar stops in Anatolian and Proto-Indo-European (p. 83). I have argued that the plain velar series developed from depalatalization of the palatovelars and delabialization of the labiovelars (e.g. 2009: 27-32, cf. already Meillet 1894 and Steensland 1973). Melchert lists three examples of plain velar ${ }^{\star} k$ in Luwian, viz. $k a r s ̌-~ ' c u t '<{ }^{\star} k r s$ - (cf. Kloekhorst 2008: 455), kattawatnalli- 'plaintiff < ${ }^{*} \mathrm{kH}_{2}$ et- (cf. Kloekhorst 2008: 466), and kiš'comb' < ${ }^{\star} k s$ - (cf. Kloekhorst 2008: 481f.), all of them with depalatalization of an original palatovelar before the following consonant. Contrary to Isaac's

"neutralisation of distinctive aspiration in the voiced occlusives" during a "period of contact between Celtic, Balto-Slavic and Indo-Iranian around 2,00o BC" (p. 90), I assume loss of PIE glottalization in Proto-Celtic and its preservation in Indo-Iranian, Balto-Slavic, Germanic, Italic, Greek and Armenian (e.g. 1985 and 2007: 149-151). In my view, Italo-Celtic was the first branch of Indo-European which separated from the proto-language after Anatolian and Tocharian and did not therefore participate in the more recent innovations of the central dialects such as the extended development of the subjunctive, the optative and the middle voice (cf. Kortlandt 2007: 151-157). Isaac's view that the sigmatic formations "are patent innovations of the late Proto-IndoEuropean period" (p. 93) is surely mistaken. Contrary to his statement, the relative pronoun ${ }^{*}$ yos was not a common innovation of Indo-Iranian, Balto-Slavic, GraecoPhrygian and Celtic but was simply replaced by ${ }^{\star} k^{w} O$ - in Germanic and Italic, just as it recently was in most Slavic languages. Celtic never was a central Indo-European language.

5. Isaac's final chapter deals with palatalization in Irish, which I have discussed earlier (1979: 41-48 = 2007: 9-17 and 1997b = 2007: 117-120). He starts from McCone's treatment (1996) without taking my criticism into consideration. Under these circumstances it seems pointless to repeat what I have said earlier about the mistakes in McCone's account and I simply refer to my earlier work. Just for the record I only mention that McCone's first, second and third palatalizations correspond roughly to my stages 7, 12 and 18 and the labialization of ${ }^{{ }^{*}} i$ to ${ }^{*} u$ in $c r u t h$ 'shape' and gen.sg. cruimthir $<$ QRIMITIR 'priest' to my stages 9 and 16, respectively. Eventually Isaac arrives at a chronology which is very close to mine (p. 102): first palatalization (7), lowering (11), second palatalization (12), apocope (15), labialization in cruimthir (16), third palatalization (18), syncope (19). Isaac's effort to conflate "the various palatalisations of Proto-Irish" (p. 104), which is evidently meant to remedy the inconsistencies in McCone's account, does not contribute to a better understanding of the chronological processes. There can be little doubt that the first palatalization affected initial consonants but not ${ }^{{ }^{*}} k^{W} r$ - and ${ }^{\star} g W$ - (cf. Kortlandt 2007: 119f.), just as the intervening ${ }^{*} W$ blocked palatalization of the velar obstruent by the following front vowel in Czech květ 'flower', hvězda 'star', unlike Russian cvet, zvezdá. The lowering 
of *e in Old Irish daig 'flame', dat.sg. taig 'house', laigid 'lies', but not in gen.sg. and nom.pl. tige, verbal noun lige, is a result of palatal dissimilation and must be dated after the general raising and lowering (cf. Kortlandt 2007: 141). I conclude that Isaac's discussion has given me no reason to change my mind on any of the issues involved.

\section{References}

Dybo, Vladimir A. 1961. Sokraščenie dolgot v kel'to-italijskix jazykax i ego značenie dlja balto-slavjanskoj i indo-evropejskoj akcentologii. Voprosy slavjanskogo jazykoznanija 5, 9-34.

Greene, David. 1976. The diphthongs of Old Irish. Eriu 27, 26-45.

Illič-Svityč, Vladislav M. 1962. K istolkovaniju akcentuacionnyx sootvetstvij v kel'toitalijskom i balto-slavjanskom. Kratkie soobščenija Instituta slavjanovedenija AN SSSR 35, 63-72.

Irslinger, Britta S. 2002. Abstrakta mit Dentalsuffixen im Altirischen (Heidelberg: Winter).

Isaac, Graham R. 2007. Studies in Celtic sound changes and their chronology (Innsbruck: Universität).

Kloekhorst, Alwin. 2008. Etymological dictionary of the Hittite inherited lexicon (Leiden: Brill).

Kortlandt, Frederik. 1979. The Old Irish absolute and conjunct endings and questions of relative chronology. Ériu 30, 35-53.

Kortlandt, Frederik. 1981. More evidence for Italo-Celtic. Ériu 32, 1-22.

Kortlandt, Frederik. 1982. Phonemicization and rephonemicization of the Old Irish mutations. Ériu 33, 73-83.

Kortlandt, Frederik. 1984. Old Irish subjunctives and futures and their Proto-IndoEuropean origins. Ériu 35, 179-187.

Kortlandt, Frederik. 1985. Proto-Indo-European glottalic stops: The comparative evidence. Folia Linguistica Historica 6/2, 183-201.

Kortlandt, Frederik. 1997a. Thematic and athematic verb forms in Old Irish. Sound law and analogy: Papers in honor of Robert S.P. Beekes on the occasion of his 6oth birthday (Amsterdam: Rodopi), 133-137.

Kortlandt, Frederik. 1997b. On the relative chronology of Celtic sound changes.

Historische Sprachforschung 110/2, 248-251.

Kortlandt, Frederik. 2007. Italo-Celtic origins and prehistoric development of the Irish language (Amsterdam: Rodopi).

Kortlandt, Frederik. 2009. Baltica \& Balto-Slavica (Amsterdam: Rodopi).

McCone, Kim. 1996. Towards a relative chronology of ancient and medieval Celtic sound change (Maynooth: Department of Old Irish).

Meillet, Antoine. 1894. De quelques difficultés de la théorie des gutturales indoeuropéennes. Mémoires de la Société de Linguistique de Paris 8, 277-304.

Melchert, H. Craig. 1994. Anatolian historical phonology (Amsterdam: Rodopi).

Rasmussen, Jens E. 1999. Selected papers on Indo-European linguistics (Copenhagen:

Museum Tusculanum).

Schrijver, Peter. 1991. The reflexes of the Proto-Indo-European laryngeals in Latin (Amsterdam: Rodopi).

Schrijver, Peter. 1995. Studies in British Celtic historical phonology (Amsterdam:

Rodopi). 
Steensland, Lars. 1973. Die Distribution der urindogermanischen sogenannten Gutturale (Uppsala: Universität).

Thurneysen, Rudolf. 1946. A grammar of Old Irish (Dublin: DIAS).

de Vaan, Michiel. 2008. Etymological dictionary of Latin and the other Italic languages (Leiden: Brill).

Winter, Werner. 1965. Tocharian evidence. Evidence for laryngeals (The Hague:

Mouton), 190-211. 